\title{
Dinámicas del encierro Policial, asfixia y juego de la verdad en La sartén por el mango (Manuel Antín, 1972)
}

\author{
Jorge Sala
}

Recibido: 30.10.2020 — Aceptado: 13.11.2020

\section{Titre / Title/ Titolo}

Dynamique de le confinement. Crime, suffocation et jeux de la veritè dans La sartén por el mango (Manuel Antín, 1972)

Confinement Dynamics. Crime, Suffocation and Truth Games in La sartén por el mango (Manuel Antín, 1972)

Dinamiche de confinamento. Crimine, soffocamento e giochi di verità nel La sartén por el mango (Manuel Antín, 1972)

\section{Resumen / Résumé / Abstract / Riassunto}

El escrito analiza la traslación cinematográfica que Manuel Antín efectuó de la obra teatral de Javier Portales La sartén por el mango (1972). Se examinará el modo en que el filme propone un cruce productivo entre el género policial y el drama psicológico. A su vez, se observará cómo la estrategia de puesta en escena que consiste en reducir la situación dramática a un único espacio cerrado se relaciona con la aparición de 'el juego de la verdad'. Este procedimiento, de raíz teatral, permitirá establecer cruces entre estas obras con otros ejemplos contemporáneos del cine y el teatro.

Cet article analyse le traduction cinématographique que Manuel Antín a faite de la pièce de Javier Portales La sartén por el mango (1972). Nous examinerons la façon dont il film propose une croisement productive entre le film policier et le drame psychologique. Également, nous observerons comment se rapporte la stratégie de mise en scène qui limite l'action à un escpae clos avec l'apparition des 'jeux de la vérité'. Cette procédure, d'origine théâtrale, permettra d'etablir croise entre ces pieces et autres exemples contemporains du cinema et du théâtre.

This study analyzes Manuel Antín's cinematographic translation made of Javier Portales's play La sartén por el mango (1972). It seeks to show the way in which the film proposes a productive intersection between the police genre and the psychological drama. At the same time, we shall point out how the staging strategy that consists of reducing the dramatic situation to a single closed space is related to the appearance of 'truth games'. This procedure, with theatrical roots, will make it possible to establish crosses between these works with other contemporary examples of cinema and theater.

Questo articolo analizza la traduzione cinematografica di Manuel Antín del testo teatrale di Javier Portales La sartén por el mango (1972). Esamineremo il modo in cui il film propone un incrocio produttivo tra il film poliziesco e il drama psicologico. Allo stesso tempo, osservermo come si realizza la strategia di ridurre l'azione drammatica in uno spazio chiuso e i rapporti con i 'giochi di verità'. Questa procedura, di origine teatrale, permetterà di stabilire incroci tra questi lavori e altri esempi contemporanei di cinema e teatro.

\section{Palabras clave I Mots-clé I Key words /Parole chiave}

Reescritura cinematográfica, encierro, policial, años setenta.

Réécriture de film, confinement, film policier, 1970s.

Cinematographic translation, confinement, crime film, seventies.

Riscrittura di film, confinamento, film poliziesco, 1970s. 


\section{El retorno a los géneros en el cine argentino de los años setenta}

Luego del cimbronazo que marcó para la historia del cine argentino la consolidación - y el conflictivo vínculo con los sectores dominantes- de la modernidad cinematográfica iniciada a principios de los años sesenta, la década siguiente se recorta como un momento particular de redefinición de las relaciones al interior del campo artístico local. Signados por la intensificación de las luchas sociales, por el incremento de la violencia y la urgencia política, pero también por la aceptación que el gran público dio a algunas películas nacionales prohijadas por los directores provenientes de dicho movimiento, los setenta o, más exactamente, los años previos a la instauración de la última dictadura cívico-militar en 1976, aparecen como una etapa rica en matices que todavía deben revisarse en profundidad.

Una de las razones de la aceptación masiva que alcanzaron ciertas películas de esos años tuvo que ver, con toda seguridad, con el acercamiento que ensayaron a los mecanismos estilísticos y narrativos provistas por los géneros tradicionales y que, a la sazón, habían sido desplazados del imaginario de los cineastas durante el estallido de la modernidad. Si el melodrama, las distintas variantes de la comedia o el policial fueron claves dentro del andamiaje del cine clásico durante sus años de oro entre los treinta y los cincuenta, estos fueron ampliamente cuestionados por aquellos 'parricidas' surgidos a posteriori que buscaron formular, ya sea una aproximación al relato realista de manera crítica o, también, unos filmes basados en la expresión de la intimidad mental y subjetiva de sus protagonistas. Esto no pretende afirmar, en modo alguno, que el cine de género haya desaparecido luego de la crisis del modelo clásico. En Argentina continuó teniendo sus adeptos en aquellos directores asociados a los parámetros industriales como fue el caso de Enrique Carreras con la comedia familiar o de Emilio Vieyra con el policial; a su vez, tampoco puede desconocerse que, en sus primeras incursiones, los directores moder- nos a quienes se suele agrupar dentro de la 'Generación del 60' persistieron algunos rasgos genéricos, aunque el modo en que los encararon iba a contrapelo de un tratamiento ortodoxo de sus elementos. Simón Feldman, por ejemplo, utilizó la comedia para desarrollar su crítica política, a la manera de Luis García Berlanga, en su ópera prima El negoción (1959). Lo mismo cabe para la relectura del melodrama de la pareja imposible interclasista que se dibuja en los protagonistas de su segundo trabajo, Los de la mesa 10 (1960). Sin embargo, como sugiere Domènec Font para el caso europeo, en Argentina «el cineasta moderno no respeta al pie de la letra los códigos genéricos, más bien los utiliza como colchones para trazar desde la condición pragmática del género un gesto propio que trasciende todo postulado clasicista» (62). Este es, por ejemplo, el tipo de acercamiento al melodrama ensayado por Leopoldo Torre Nilsson en sus trabajos junto a Elsa Daniel —Graciela (1956), La casa del ángel (1957), La caída (1960) y La mano en la trampa (1961) — en los que las reminiscencias a los patrones genéricos sirven «de vehículo a cuestiones como las normas del orden social, los valores de la filiación política y generacional, los enfrentamientos de clase ocultos o desembozados» (Amado, 356).

Como se mencionó anteriormente, los cineastas de la «Generación» tomaron, en mayor o menor medida, distancia de los formatos preestablecidos para inclinarse, en cambio, por las exploraciones realistas o bien por el camino de la introspección subjetiva. Los primeros trabajos de Feldman, Rodolfo Kuhn, David Kohon, Manuel Antín, José Martínez Suárez y Lautaro Murúa revelaron en el país la posibilidad de conformación de un cine intelectual, emparentado con las innovaciones de las nuevas olas europeas en igual medida que con las transformaciones operadas en el teatro, la narrativa y el campo cultural locales. Y, al igual que lo que sucedió con muchos productos de los nuevos cines emergentes en los sesenta, su recepción fue acotada y en cierto modo quedó restringida a los circuitos no mayoritarios de exhibición.

Si este fue el panorama generalizado de la modernización cinematográfica en sus primeros años, la situa- 
ción cambiaría paulatinamente hacia la segunda mitad de los sesenta. Y en esto, aunque no fue el único factor condicionante, tuvo mucho que ver la incorporación de las matrices genéricas en el desarrollo de los relatos. La primera incursión de los cineastas jóvenes alrededor de este problema fue la llevada a cabo por Rodolfo Kuhn en Pajarito Gómez —una vida feliz- (1965), en la que el director se valía de diversos recursos cómicos para elaborar una sátira sobre los mass media - la industria discográfica, las fotonovelas, la televisión y la radio- que tomaba como eje la vida de un cantante nuevaolero. Más allá de este filme, que abrió una nueva senda de reflexión crítica sobre las relaciones entre el cine con los medios masivos, el encuentro de los artífices con el gran público se produjo tiempo después. Torre Nilsson abrió un circuito de aceptación masiva a partir de la traslación del clásico de la literatura argentina Martín Fierro (1968). En la brecha abierta por este director se sitúan algunas propuestas de los cineastas modernos que alcanzaron amplia repercusión en la platea: El santo de la espada (Torre Nilsson, 1970), una biografía del General José de San Martín que no desconocía su ligazón con el modelo del drama social-histórico tan en boga durante los años de oro de la cinematografía clásica vernácula, Don segundo Sombra (Manuel Antín, 1969), también basada en otro texto canónico de la gauchesca, Con alma y vida (David Kohon, 1970), una historia de delincuentes, Güemes, la tierra en armas (Torre Nilsson, 1971) y dos de los mayores éxitos de la cinematografía nacional del período: Juan Moreira (1971) y Nazareno Cruzy el lobo (1973), ambas de Leonardo Favio. Todas estas reconocen sin reparos sus deudas con los modelos genéricos -el drama histórico, la épica gauchesca, el melodrama-, buceando en sus aguas para allanar un camino de acceso al gran público.

En ese contexto se produce el estreno de La sartén por el mango (Antín, 1972). No se trató de una experiencia exitosa, sino todo lo contrario. Pese a sus pretensiones, visibles en el armado del elenco y en la difusión desplegada en la prensa, esta incursión fue un rotundo fracaso de taquilla. Por otra parte, Antín siempre la asumió como un trabajo de compromiso, una obra olvidable al punto que nunca se refirió a ella como parte de lo que consideró lo significativo de su trayectoria. Y, no obstante, esta película conlleva algún interés histórico por varias razones. En primer lugar, se trata de la única traslación del director de una pieza teatral. Mientras su cine anterior se conjugó en gran medida emparentado con las búsquedas de la literatura del momento (Julio Cortázar y Augusto Roa Bastos), aquí decidió llevar a la pantalla casi inmediatamente lo que había sido un éxito en las tablas locales. En segundo lugar, este filme, construido en apariencia sobre la intriga policial del descubrimiento del responsable de un crimen (el tan mentado whodunit), se instala sobre la matriz genérica como excusa para apuntar hacia otros territorios ajenos, en su caso el drama psicológico ligado a la revelación de la verdad de los personajes. Este dato, contrariamente a lo que la crítica posterior ha visto al revisar la obra del director, permite enlazar La sartén por el mango con las búsquedas arrojadas en sus primeras películas. Por último, pero no menos importante, el retorno a lo intimista que define el tono del filme toma partido por el anclaje en dos procedimientos de asimilación cinematográfica de lo teatral, el encierro en un espacio único y la asunción del 'juego de la verdad', que fueron herramientas centrales dentro de la relación entre el cine y el teatro modernos del período (Sala, 2020) y que el filme lleva a un extremo a partir del trabajo de la puesta en escena. Sobre estos ejes se desarrollará el análisis de la reescritura de esta obra, procurando encontrar puntos de encuentro con otras producciones, tanto teatrales como cinematográficas, estrenadas contemporáneamente.

\section{El encuentro entre el autor $y$ el director}

En mayo de 1972 el actor Javier Portales, que ya contaba con alguna experiencia como guionista de televisión, ${ }^{1}$ dio a conocer en el Teatro Olimpia la pieza de su autoría La sartén por el mango con una apreciable repercusión por

A fines de los sesenta Portales colaboraba como guionista de libretos junto a Narciso Ibáñez Serrador; en 1970 tuvo a su cargo la autoría de un programa de unitarios: Ciclosis. 
parte del público. En un clima social en el que la violencia hacía mella en la cotidianeidad de los espectadores de clase media (Carassai, 2013), el juego descarnado desarrollado en ella obtuvo una repercusión inusitada. Su historia, cercana al teatro realista cuestionador de los comportamientos de esa misma clase, era sencilla: cuatro amigos salen de copas celebrando la despedida de solteros de uno de ellos. Llegan al departamento del protagonista y deciden invitar a unas prostitutas para terminar la noche con ellas. Repentinamente una de las mujeres muere y José (el dueño de casa) decide encerrar a todos hasta aclarar quién es el responsable del misterioso crimen. No obstante, como se verá a continuación, esta será la excusa para establecer un juego de violencia interna en la que se busca revelar las verdades de los diferentes personajes.

Osvaldo Bonet dirigió la puesta que contó con las actuaciones del mismo Portales en el papel protagónico, acompañado por Enrique Liporace, Betiana Blum los dos únicos nombres que más tarde permanecieron dentro del elenco de la versión cinematográfica- Virginia Ameztoy, Julio de Grazia, Silvia Merlino, Enzo Bai y Andrea Yasky. En el programa de mano, un escrito de Arnoldo Liberman proponía una orientación de lectura sobre la obra que esbozaba desde el principio la importancia de los vectores espaciales. Allí podía leerse:

Living-comedor y dormitorio a continuación, conformando un solo decorado. Es un departamento moderno ubicado en un séptimo piso. Hay un ventanal por el cual puede verse la ciudad. Sin dar sensación de abandono, salta a simple vista, por algunos detalles de su ambientación, que el mismo está habitado por un hombre solo. Estas palabras del autor son, quizá, un breve, desnudo anticipo de la esencia misma de la obra. Javier Portales (...) plantea así algo que trasciende en mucho las indicaciones técnicas: Un hombre solo, un ventanal a la ciudad, un grupo de hombres solos como los tantos que habitan esta ciudad que nos duele y nos empuja en medio de la incertidumbre y el abismo.

El encierro como mecanismo propiciatorio para la emergencia de la identidad oculta de los comportamientos ocultos tras un velo de apariencias fue un tópico insistentemente trabajado por los teatristas argentinos a lo largo de los sesenta. Mientras en el plano internacional se daban a conocer propuestas que atendían esta temática —entre las más conocidas pueden mencionarse Huis clos, de Jean-Paul Sartre o ¿Quién le teme a Virginia Woolf?, de Edward Albee ${ }^{2}$ - los teatros porteños recuperaron dicha vertiente de manera productiva. La estrecha ligazón entre inmovilidad y efervescencia de las pasiones rindió sus frutos en piezas como Soledad para cuatro (Ricardo Halac, 1962), intensificándose en las puestas de $\dot{i} A$ qué jugamos? (Carlos Gorostiza) y Se acabó la diversión (Juan Carlos Gené), ambas de 1968. El cine local, por su parte, también valorizó este tratamiento emparentado tanto con las 'puertas cerradas' de Sartre al igual que con El ángel exterminador buñueliano (1962) en películas como La terraza (Leopoldo Torre Nilsson, 1963) y Los herederos (David Stivel, 1970). En estos filmes, análogamente a lo que ocurre en la versión cinematográfica de La sartén por el mango, la asfixia experimentada por los sujetos en función de la imposibilidad de abandonar el lugar que los oprime termina propiciando el surgimiento de instancias de revelación de la verdad a partir del discurso descarnado de los personajes. En una reseña crítica sobre la versión teatral de la obra de Portales, el periodista bosquejaba las filiaciones entre esta obra y los respectivos trabajos de Jean-Paul Sartre y Luis Buñuel:

En "La sartén por el mango" hay mucho del infierno que está entre las cuatro paredes donde el filósofo francés aisló del mundo a sus personajes y también de la casa de los "prisioneros", a la que nadie tiene acceso, pese a que tampoco nadie lo impide, utilizada por el cáustico director español para encerrar los prejuicios de los individuos. ${ }^{3}$

El encierro como factor desencadenante del juego de la verdad cobrará fuerza también en la medida en

La obra se presentó por primera vez el 13 de octubre de 1962 en el Billy Rose Theatre de Brodway. En Buenos Aires fue montada en el circuito comercial por Luis Mottura en 1964 en el teatro Regina con un elenco conformado por Myriam de Urquijo, Ignacio Quirós, Selva Alemán y Emilio Alfaro. Pellettieri (142) vincula la trascendencia que tuvo esta puesta como motor que intervino en la configuración del hiperrealismo argentino de ¿A qué jugamos? y Se acabó la diversión. En este sentido, el intertexto de Albee funcionó como un efectivo aliciente para el desarrollo de un teatro (y un cine) asociado al 'juego de la verdad'.

S/F: «Revelose un actor como autor teatral», La Nación, 23/05/1972. 
que los amigos, desprovistos de un contexto que funcione como un elemento apaciguador o distractivo, se vean obligados a exponer sus miserias frente a los espectadores. Más que situados en un entorno específico, los personajes parecen desenvolverse en un espacio abstracto que busca dejar sentada la ahistoricidad del tema tratado a través de la negación de marcas de reconocimiento. Refiriéndose a los temas que atraviesan su obra, Portales reflexionaba años después:

El tema que a mí me preocupa es el hombre esencialmente. El hombre como ente comunicante. En sociedad. La amistad, las situaciones límite, sus reacciones atemporales. Y cuando digo atemporales, quiero decir exactamente eso: más allá de los condicionamientos históricos, el hombre es lo que lleva adentro. Es el alma. Son sus grandezas y sus miserias. ${ }^{4}$

La búsqueda atenta a escarbar en problemáticas trascendentales del ser humano, más allá de los apuntes históricos específicos constituye una de las razones que llevaron al autor a encerrar a sus criaturas como excusa que facilitaba analizar microscópicamente las conductas sin la necesidad de delinear trazos demasiado precisos sobre el contexto inmediato. En este punto, Javier Portales coincide, probablemente sin saberlo, con lo que Manuel Antín expresaba a principios de los sesenta, es decir, cuando este último recién iniciaba su carrera como director. En la época de sus primeros largometrajes, el cineasta manifestaba una preocupación similar en la que la coyuntura histórica, «el contorno», pasaba a segundo plano frente al protagonismo asumido por las vivencias de los sujetos en otro orden. «La realidad es una especie de cosa fantasmal que nos rodea y nos hace bien» decía Antín contraponiéndose a aquellos realizadores que, como Lautaro Murúa o Martínez Suárez, buscaban dejar la huella de los problemas sociales del presente en sus películas. Continúa: «Tanto en La cifra impar [(1962)] como en Los venerables todos [(1962)] esta realidad actúa de un modo abstracto: no es necesario decir que un vaso es un vaso, es necesario simplemente sugerirlo porque la presencia del vaso es

Horacio Delmastro: «La televisión la hacen los que no saben», Ahora, 01/11/1984. bien clara de por sís. ${ }^{5}$ En esta idea de partir del realismo para construir un discurso que lo trasciende al evidenciar preocupaciones de otro orden es donde se produce el encuentro entre el cineasta y el autor dramático.

Después de haber favorecido un cambio de rumbo hacia la expresión más abierta de contenidos políticos y sociales en una película como Castigo al traidor (1966) y de revisar -en su doble acepción: como acción de retomar el pasado y como posicionamiento teórico-ideológico- la tradición literaria y la Historia nacional en otros dos títulos, Don Segundo Sombra y Juan Manuel de Rosas (1972), Antín decidió volver a los relatos intimistas de principios de los sesenta. Los resultados desastrosos en términos monetarios que tuvo que afrontar tras esta última incitaron al director a inclinarse hacia un tipo de ficción que no implicara apostar demasiado alto en lo referente a despliegue de producción y costos.

«Sé que éste fue un proyecto que desconcertó a todo el mundo - hasta a mi-, fundamentalmente porque no se confiaba en una obra tan seria de Portales, tradicionalmente un humorista», ${ }^{6}$ confesaba Manuel Antín en una entrevista durante el rodaje de la película. Sin embargo, pese al lugar anómalo en el que suele ubicarse a La sartén por el mango dentro de los estudios sobre su trayectoria fílmica (Cfr. Oubiña; Torlucci) su única incursión en el terreno de la reescritura de obras de teatro conserva un interés por sellar el retorno a las formas menores e íntimas sin por ello renunciar a la necesidad de obtener una mayor aceptación por parte del público a través de los elementos provistos por el cine de género.

\section{Espacio claustrofóbico y 'juego de la verdad'}

El propio Antín reconocía que, desde Castigo al traidor, su obra atravesaba por «una etapa menos fantasmagó-

Ambas citas pertenecen al artículo de Franco Mogni: «Reportaje a Manuel Antín» Tiempo de cine, Año II, No 12, diciembre de 1962. Para un análisis de las discusiones de los realizadores alrededor de la importancia otorgada al apego cinematográfico a la realidad y a sus implicancias en términos de configuración de un cine vinculado al presente histórico puede consultarse el trabajo de Jorge Sala (Las nociones, 93-106). S/F: «Habla Manuel Antín. 'Nadie esperaba esto de mi’», Clarín, 31/08/1972. 
rica y personal, menos abstracta y onírica, más concreta y cercana a ciertos aspectos muy materiales de la realidad» (Sández, 82). Retomar una puesta teatral realista, próxima al psicodrama, cuyo leitmotiv es la inmovilidad de los cuerpos como factor desencadenante de la verdad resulta una solución lógica de la que surgen, conjugados, el deseo de objetividad material y la recuperación del intimismo. Un deseo, por otra parte, no carente de intenciones comerciales, como prueba el hecho de haberse valido de una pieza exitosa y, asimismo, de convocar para el papel protagónico a Claudio García Satur, por esa época en el apogeo de su fama como protagonista de la telenovela Rolando Rivas, taxista, quien ocupó el papel de José que en la puesta teatral encarnaba el propio Javier Portales. Un cambio que, no solamente alejaba al autor ${ }^{7}$ del texto en el que se basaba la película, sino que también tendía a afinar los sentidos de un personaje pensado bajo otras características. Según el cartel publicitario de la película, el rostro en primer plano de García Satur intentaba capturar la atención de los fanáticos al tiempo que anticipaba una definición: «canchero, prepotente, ganador hasta la rabia y el odio», adjetivos totalmente ajenos a lo que podía significar la construcción estelar de Portales para el público y que, en cambio, en el galán televisivo cuajaban a la perfección o, por lo menos, generaban una incertidumbre que el visionado del filme vendría a resolver.

La película se instala como una suerte de síntesis, aunque fallida, entre el realismo subjetivo de sus primeros títulos y las prerrogativas comerciales que habían quedado abiertas en sus realizaciones históricas. Previo a su estreno, un artículo publicado en Clarín proponía una lectura tendiente a ubicar a La sartén por el mango como una continuación necesaria de toda su obra anterior:

La actual es para Antín hora de acercamientos masivos. Sin rayar en el enorme suceso que él y sus productores descontaban,

Aunque en los reportajes realizados durante el rodaje de la película Antín declaró haber trabajado junto a Portales en la traslación del texto, este último no aparece en los rubros artísticos más que como autor de la pieza original. Según comentarios de Javier Álvarez, hijo de Javier Portales, su padre se limitó a vender los derechos de adaptación cinematográfica de la obra y no tuvo intervención alguna en una película que, por otra parte, nunca resultó ser de su agrado. Entrevista personal mantenida el 25 de octubre de 2014.
'Rosas' fue obra de grandes plateas. Como había sido 'Don segundo Sombra' y como, mediante un título, un elenco y una vigencia, también podría serlo 'La Sartén por el mango'... ${ }^{8}$

La pieza de Portales se inicia, continuando con la premisa abierta en ¿Quién le teme a Virginia Woolf?, con una situación festiva: al igual que George y Martha en la pieza de Albee, los cuatro amigos llegan borrachos al departamento de José y deciden llamar a las prostitutas para finalizar la noche. La distensión que define las acciones de los personajes en estos tramos iniciales permite pensar en primera instancia en una comedia con algunas dosis calculadas de erotismo. En la puesta, este prólogo opera como una instancia de base ajena al espacio único en el que se desarrolla el relato a la vez que como mecanismo introductorio de la prehistoria de las relaciones entre los personajes. Si en la obra de Albee la cena de camaradería de los académicos permanecía como un momento anterior al presente de las acciones, en el caso de La sartén... los festejos aparecen efectivamente mostrados al principio, aunque esbozados en un espacio indefinido que no interfiere en la unidad de lugar propuesto para el resto de la pieza. Las didascalias que abren un cuadro que en el texto se denomina 'momento primero' marcan esta introducción del exterior como forma de contraste con el encierro que se experimentará a continuación:

La calle, una cualquiera. A criterio del director la escena puede desarrollarse con el telón bajo y frente al mismo, o en caso contrario ocuparse un sector del escenario para ambientar el decorado anteriormente citado. Cuando la luz ilumina la escena a poco comienza a escucharse de entre cajas, voces que acercándose cantan. Estas suenan de manera especial. No guardan un orden, desafinadas, monocordes, agudas. Es el producto que dejó una comida abundante y una bebida copiosa (2). ${ }^{?}$

\footnotetext{
Carlos Moreno: «Manuel Antín: A la búsqueda del gran público y la tutela de sus creencias», Clarín, 01/10/1972.

El texto dramático de La sartén por el mango nunca fue publicado. El párrafo citado $\mathrm{y}$ todas las referencias siguientes pertenecen al original mecanografiado, fechado en Buenos Aires, el 19 de octubre de 1971. Una copia del mismo fue facilitada por Javier Álvarez. Aprovecho este espacio para agradecerle la generosidad que tuvo al acercarme este material, al igual que la posibilidad de acceder al archivo personal de su padre.
} 
La reescritura de Antín recobra en su iconografía la antítesis espacial formulada en la apertura de la obra teatral. En el prólogo de la película las imágenes urbanas, los autos y las luces del centro se contraponen a la clausura que impera tras la llegada de los hombres al lugar donde los esperan las mujeres convocadas anticipadamente por José. Si un atisbo de referencialidad surgía en el hecho de hacer circular a los cuatro hombres por la calle, esto se verá depurado a partir del ingreso al departamento. La puesta en escena, desde este momento, no abandonará la unicidad espacial.

Idénticamente al efecto de contraste establecido por la presencia del espacio abierto (la calle) al inicio de la obra, el strip-tease de Carmen que precede a su fallecimiento marca un límite en el que la teatralidad subrayada cede su lugar frente al avance del realismo más descarnado. En la puesta original, la situación se conjugaba como un momento de aparición de teatro dentro del teatro en la que los personajes observan atentos el espectáculo de la desnudez femenina:

\footnotetext{
JOSÉ: ...(Llama la atención golpeando las manos. Habla como un locutor profesional) Bueno... y ahora, señoras y señores, vamos al número central de la noche (señala a Carmen). Carmen... la exquisita Carmen nos brindará un Streep-tease...

TODOS: Muy bien... bravo!!

LUCY: Después lo hago yo...

CARLOS: Si... si... Después lo hacemos todos!!

JOSÉ: (Toma de una mano a Carmen y la lleva al sitio donde esta hará su número) Un aplauso para la artista!! (14)
}

Antín recobra el mismo disparador incorporándolo en una escena que realza, en consonancia con la disposición del original, la teatralidad de la situación. Lo cinematográfico y lo teatral aparecen con fuerza complementándose con una única salvedad: en virtud del traspaso al cine, la escena adopta la fisonomía de un «momento de teatro» (Tesson, 44-49), enmarcado por los límites de la pantalla. En la película de Antín, el montaje y los movimientos de la cámara impugnan la acusación de haber caído en el «teatro filmado». No obstante, reconociendo la procedencia de esta escena, los hombres y mujeres quedan dispuestos en los sillo- nes del living como el público de una puesta teatral; son filmados en varios planos de espaldas, con una cámara colocada a gran distancia que reencuadra la imagen de Carmen desvistiéndose rodeada por unos espectadores atentos. Fortaleciendo la idea de un espectáculo dentro de otro, la actriz (Elizabeth Makar) se desnuda y en varios momentos mira directamente a la cámara incitando con sus gestos a una posible participación de la platea, aquella situada al mismo tiempo adentro y fuera de la pantalla.

Tras una muerte que define, continuando con la lógica anteriormente descripta, la cesura de lo impostado, de lo teatral entendido como espectáculo pasatista y, podría pensarse, como sede de lo artificial, sobreviene el imperativo de abandonar la literalidad de la desnudez real y avanzar hacia la desnudez simbólica de los sujetos. La frase de Carlos -«Si... si... Después lo hacemos todos!!», el personaje que a la postre terminará más afectado por las verdades puestas en juego, cobra otro significado cuando la trama abandona su afincamiento inicial en la comedia picaresca para adentrarse en la vía sinuosa del drama psicológico.

Con la muerte como testigo presencial -el cuerpo de Carmen permanece todo el tiempo en la escena, solo tapado por una manta - la obra busca develar la identidad de los personajes. Asumiendo un giro al policial, el relato pretende hacer surgir la realidad que permaneció hasta entonces oculta tras diversas máscaras. Según el juego propuesto por la pieza, esto solo es posible una vez que se establece la clausura del espacio. La imposibilidad de salir genera no sólo un clima opresivo. Así, la concentración de la situación en un lugar del que no se puede escapar funcionará como motor desencadenante de las acciones:

JOSÉ: (...) Pero es necesario que todos asumamos la responsabilidad (Pequeña pausa, lo miran). Me explico, verdad?

NENÉ: Qué querés decir...?

JOSÉ: En el momento que Carmen murió, todos estábamos presentes... (Mientras dice esto último ha ido caminando lentamente hasta la puerta de salida del departamento y queda allî). CARLOS: Mirá con la novedad con la que salís ahora...

LUCAS: (Cortante) Querés callarte!! 
ESTEBAN: (Intrigado) Y eso que tiene que ver...?

JOSÉ: (Firme) Que nadie saldrá de aquí hasta que avisemos a quien corresponda sobre esta muerte!! (Hace girar la llave de la puerta del departamento y termina por guardarla en uno de sus bolsillos. Sorpresa general)

(...)

ANDREA: (Sin entender) Qué pasa ahora...? Por qué nos encerrás?

JOSÉ: (Seguro) Ya se los dije. Lo único que hago ahora es asegurarme que nadie saldrá del departamento, al menos por esta puerta. No hay otra salida como no sea esa ventana;... y estamos en un séptimo piso. (21-22)

Apuntando al imperativo de asumir las responsabilidades, José, quien provoca la muerte de Carmen envenenándola, encierra a los demás induciéndolos a experimentar el juego de la verdad. A diferencia de otros filmes y puestas teatrales en los que este tópico aparecía -La terraza o Los herederos, ¿A qué jugamos? o Se acabó la diversión- en la pieza de Portales y en la reescritura de Antín la emergencia de la verdad conjuga una demanda psicologista/teatralista de desenmascaramiento con un procedimiento de índole policial. Lo que se trata de descubrir en la trama de La sartén por el mango es, en primera instancia, al culpable de la muerte. Una vez atravesado esto, aparecerá la cuestión de la revelación de las identidades como tema predominante. Como gesto intolerable, la situación límite convoca la aparición de la honestidad en unos personajes desesperados. La revelación de los rostros ocultos tras las máscaras de las convenciones, expresada tanto en la obra teatral como en la fílmica mediante una catarata de insultos y gritos, deja traslucir el odio existente entre todos. A medida que avanza el relato, el policial pierde densidad, la muerte se desvanece para dar paso al reproche y la venganza de José, convertido en justiciero por mano propia de las tropelías cometidas contra él.

Se trata, en suma, de un conflicto original en tanto no necesita recurrir a instancias metafísicas (como en Sartre) o inexplicables (como en Buñuel) que justifiquen la clausura a la que se ven arrojados los sujetos. Al no haber constricciones externas que impongan la inmovilidad, esta surge como producto de la situación dramática misma. Aquí el realismo más llano se impo- ne: los personajes no pueden abandonar el lugar justamente porque son presas de las máscaras impuestas por sus propias convenciones sociales. Esto queda puesto de manifiesto desde el principio: entre todos deciden que lo mejor es no llamar a la policía para no quedar en evidencia frente a los demás de lo incómodo de reconocerse como unos hombres que intentaron divertirse ilícitamente con unas prostitutas (fuera de sus esposas y de sus vidas de profesionales respetables); ellas, por su parte, conocen de antemano la condena que pesa sobre lo que hacen y prefieren eludir la intervención de la ley. Todos podrían abandonar el lugar, puesto que nadie es culpable de la muerte de Carmen, pero ¿cómo hacerlo sin dejar rastros de otras situaciones también oprobiosas que los incriminan?

En la película, el efecto de contraste entre la mascarada de la vida de los personajes respecto al momento crítico que atraviesan a lo largo del relato queda determinado a partir de la inclusión sistemática de flashbacks. Estos rompen con la unidad temporal formulada por la pieza teatral apelando a una literalidad brindada por la oposición cromática: las imágenes en colores del presente se mezclan con los recuerdos en blanco y negro de los personajes. Cuando Esteban (Alberto Argibay) constata que Carmen no respira, inmediatamente sobreviene un corte abrupto que presenta una escena en exteriores. Lo bucólico de la representación de su esposa e hijos corriendo por una plaza para encontrarse y abrazarse con él plantea un enfrentamiento abierto con su realidad de testigo/cómplice de un crimen.

La incorporación de escenas en sepia funciona toda vez que los personajes rememoran algún momento anterior. En algunos casos se utiliza para situar un instante plácido en comparación con la tensión que domina las acciones formuladas en presente; en otros, el blanco y negro enmarca la rememoración de fragmentos del pasado que conducen a la asunción de la verdad. A través de este recurso, al que se adhiere una banda sonora que amplifica las voces como un eco profundizando el extrañamiento, sucede, por ejemplo, la toma de conciencia de Lucas de la traición a José en la empresa en la que trabajaban. 
El uso constante de flashbacks en la película busca traducir lo que en la jerga teatral se conoce comúnmente como «momento privado». Gustavo Geirola, definiendo el término de manera cercana a la noción de fantasma, concibe que este se produce

cuando el sujeto no piensa en sí mismo, sino en alguna cosa particular de sí mismo que difícilmente compartiría con otra persona. No es algo inconsciente, es algo que él ve de sí mismo, como si fuera actor y espectador de una misma escena. Son cosas, pues, que el sujeto puede hacer privadamente y que solo él conoce. (16)

En la obra de Portales, así como en la recuperación que efectúa Antín, estos recuerdos funcionan, a la vez que como contrapeso por su carga moral positiva con relación al presente ominoso, como un alivio dramático frente a la tensión. Asimismo, su aparición hace partícipe al espectador de una verdad sobre los personajes que nunca se torna visible para ellos mismos. La solución que el cineasta encuentra, por otra parte, no deja de provocar cortocircuitos por su artificiosidad con relación a un discurso anclado en el realismo. Pero, con todo, el cruce entre color y sepia o, más exactamente, el pivote entre presente y pasado se integra a esta lógica de una manera menos arbitraria que los apartes y, en general, la verborrea que dominan la puesta teatral. A través de este mecanismo, los personajes comienzan a desandar el nudo de sus conflictivas relaciones interpersonales:

LUCAS: (habla como para sî) Pienso lo que sería de mí si se enteraran... ¿Quién era yo hace unos años? Un don nadie... (sonríe amargo) Boleto de ómnibus a las siete de la mañana...; una ficha que marcaba el sueldo básico con salario familiar incluido... (se vuelve hacia Esteban y Carlos que no lo escuchan. Cada cual en su mundo) o me fue fácil ocupar el lugar que tengo... Todo lo conseguí a fuerza de pulmón... luché... le peleé a la vida... le gané... me gané lo que soy!Hasta hoy aquello había quedado atrás... como un mal sueño (casi grita histérico) Y no estoy dispuesto a revivirlo...!No quiero...! (31-32)

Los momentos privados y las instancias de reconocimiento de la verdad son trasladados a la pantalla a partir del uso de primeros planos. En cada una de las ocasiones en que los diferentes personajes atraviesan por este proceso, la cámara los aísla del resto del conjunto. Cuando, en cambio, la puesta en escena opta por los planos de conjunto, la narración cinematográfica se resiente dejando paso a una franca teatralidad que convierte al espacio por momentos en un falso escenario de caja a la italiana y en otros a un plató de televisión.

Lo más endeble de la reescritura cinematográfica es el hecho de no cuestionar el efectismo de la situación original y la carencia de matices con las que transforma un aparente relato enmarcado en el género policial en un drama psicológico. Como señala David Oubiña,

nunca se siente la presencia del cuerpo muerto gravitando en el ambiente: más que horrorizarse por el asesinato o asombrarse por las revelaciones de quien creían un viejo amigo, los personajes parecen molestarse por los inconvenientes prácticos que la situación les ocasiona. (41)

La muerte, elemento clave del género que la película explota en un primer momento, pierde todo espesor en la medida en que se desencadenan las revelaciones de los cuatro hombres. De este modo, el desfasaje existente entre las alusiones al policial y la emergencia del relato intimista (aunque expansivo por lo exasperado de las actuaciones y por el quantum dramático que portan cada una de las intervenciones) hacen que el filme pierda densidad en su definición del tono, naufragando en la incertidumbre entre las referencias genéricas y su ruptura. No se trata, como señalaba Domènec Font en la cita del principio, de un uso personal de los géneros, sino de carencias de otro tipo: ya sea por el desconocimiento sobre los fundamentos constitutivos de todo filme basado en un crimen o bien por una decidida falta de interés por otorgarles una mayor jerarquía.

Recordando su participación dentro de la 'Generación del 60' Antín proponía que una marca común a todos los integrantes del grupo radicaba en el alejamiento de las formas tradicionales: «Nosotros no veníamos de la industria y no teníamos moldes previos ni rutinas aprendidas. Éramos vírgenes» (Peña, 34). Esta negación del pasado implicó dinamitar, entre otras cosas, los formatos genéricos (los «moldes previos») que 
fueron uno de los núcleos fundantes del cine anterior. Para los directores, supeditar la construcción de una visión personal a unos moldes preestablecidos implicaba una claudicación. De ello se traduce que La sartén por el mango, entendida como el intento de Antín por retornar a su primer cine, se juegue entre la alusión al crimen y su distanciamiento.

\section{Un cine a puertas cerradas}

Son famosas, aunque lamentablemente poco recordadas, las ideas que tenía Alfred Hitchcock sobre los modos de llevar a la pantalla grande una pieza teatral. En la célebre entrevista mantenida con François Truffaut (184-185), el director inglés proponía una política de la reescritura cinematográfica de la puesta en escena teatral -que él mismo llevó a la práctica en títulos como La soga (Rope, 1948) y Crimen perfecto (Dial M forMurder, 1954)- en la que imperaba la explotación de la concentración de las situaciones en un espacio único como una estrategia que le permitía desarrollar procedimientos cinematográficos como el plano secuencia. Según Hitchcock, el principal error de los cineastas consistía en su necesidad de expandir los espacios, de explicitar lo que en el teatro exclusivamente quedaba aludido o se intuía como parte de una extraescena que nunca debía actualizarse en imágenes.

Pese a su condición de película fallida, La sartén por el mango se erige como un ejemplar interesante de los postulados hitchcockianos sobre la reescritura fílmica de un texto dramático. En ella, las dinámicas del encierro cobran un sentido que trasciende lo temático para orientarse, como pudo comprobarse, en las búsquedas de una puesta en escena organizada en función de los encuadres provistos por la cámara. Aunque en algunos tramos la narración opera sobre la base de la bifurcación temporal a través de la inclusión de flashbacks, hay en este filme una persistencia en el sustento de la unidad espacial. En esta voluntad, reñida en cierto modo con las innovaciones propiciadas por la modernidad cinematográfica de la década anterior, radica el lugar singular de este filme dentro de la Historia del cine argentino.

Para los cineastas locales surgidos a principios de los sesenta el abandono de los platós de filmación significó un punto de quiebre con el pasado pautado por el imperativo de acercamiento al contexto inmediato. Este nuevo confinamiento entre cuatro paredes ensayado por Antín debe leerse, entonces, no como la claudicación de una prerrogativa central de la modernidad, sino como el producto de una síntesis en la cual la querella contra las mecánicas del cine clásico quedaba dejada de lado. Superados los escollos entre dos bandos en disputa fue factible volver al encierro en estudios para resignificar algunos de sus rasgos característicos.

Lo mismo cabe para las referencias marginales que La sartén por el mango utiliza del policial. Las películas de la 'Generación del 60', más ligadas a las prerrogativas realistas, a las crisis identitarias propiciadas por el existencialismo y a la falta de certezas de las acciones de los personajes no podrían haber concebido una relación productiva con los géneros canónicos. En los setenta, como se señaló al principio, el panorama había cambiado. Al igual que sucedió con varias novelas de esa época, que en Manuel Puig u Osvaldo Soriano tuvieron a sus representantes más notables en lo que refiere al desarrollo de narraciones sobre la base de matrices genéricas archiconocidas, el cine de avanzada también fue parte de este proceso de resignificación. Una tendencia que no fue otra cosa que una forma de adaptación o de asunción de las prerrogativas de la cultura popular. No solo los directores modernos fueron más permeables a su utilización, sino que los propios géneros en su continua transformación (Altman) también habilitaron los roces, los acercamientos —a veces orgánicamente y no pocas veces insospechados- con procedimientos ajenos a sus propias reglas constitutivas. En un contexto como ese, La sartén por el mango pudo fundar su propia lógica partiendo de la necesidad de revelación de la culpabilidad sobre un crimen para abordar, sin solución de continuidad, un estudio psicológico sobre personalidades en crisis arrojadas al vacío de asumir sus propias verdades en juego. 


\section{Bibliografía}

Altman, Rick. Los géneros cinematográficos. Barcelona: Paidós, 2000.

Amado, Ana. «Conflictos ideológicos, inscripciones textuales. El espacio doméstico en los melodramas fílmicos y literarios de los 50». Cine argentino. Modernidad y vanguardias. 1957-1983, Tomo I. Dir. Claudio España. Buenos Aires: Fondo Nacional de las Artes, 2005, pp. 356-363.

Carassai, Sebastián. Los años setenta de la gente común. La naturalización de la violencia. Buenos Aires: Siglo XXI, 2013.

Font, Domènec. Paisajes de la modernidad. Cine europeo 1960-1980. Barcelona: Paidós, 2002.

Geirola, Gustavo. «Aproximación lacaniana a Stanislavski: La novela familiar del Sistema». Telón de fondo. Revista de teoría y crítica teatral, 10, 2009 https:/ / www. telondefondo.org/numeros-anteriores/numero10/ articulo/227/aproximacion-lacaniana-a-stanislavski-la-novela-familiar-del-sistema.html Recuperado el 10 de octubre de 2020.

Oubiña, David. Manuel Antín. Buenos Aires: Centro Editor de América Latina, 1994.

Pellettieri, Osvaldo. Una historia interrumpida. Teatro argentino moderno (1949-1976). Buenos Aires: Galerna, 1997.
Peña, Fernando. 60/90 Generaciones. Cine argentino independiente. Buenos Aires: MALBA/Fundación Constantini, 2003.

Portales, Javier. La sartén por el mango. Buenos Aires, Original mecanografiado (inédito), 1971.

Sala, Jorge. «Las nociones de compromiso y praxis en el cine de los sesenta y la reevaluación de las prácticas emergentes» Una historia del cine político y social en Argentina (1896-1969). Eds. Ana Laura Lusnich y Pablo Piedras. Buenos Aires: Nueva Librería, 2009, pp. 93-106.

- Escenas de ruptura: Relaciones entre el cine y el teatro argentinos de los años sesenta. Bernal: Universidad Nacional de Quilmes, 2020.

Sández, Mariana. El cine de Manuel. Un recorrido sobre la obra de Manuel Antin. Buenos Aires: Capital intelectual, 2010.

Tesson, Charles. Cine y teatro. Barcelona: Paidós, 2012.

Torlucci, Sandra. «Manuel Antín. El lenguaje y sus inexplorados laberintos» Cine argentino, modernidad y vanguardias (1957-1983), Tomo II. Dir. Claudio España. Buenos Aires: Fondo Nacional de las Artes, 2005, pp. 102-111.

Truffaut, François. El cine según Hitchcock. Madrid: Alianza, 1974. 
